\title{
Journal of French Language Studies
}

\section{Note aux auteurs}

Les propositions d'articles et la correspondance doivent être envoyées à:

Professor Florence Myles

University of Essex

Department of Language and Linguistics

Wivenhoe Park

Colchester $\mathrm{CO}_{4}{ }_{3} \mathrm{SQ}$

England, UK

E-Mail: jfls@newcastle.ac.uk

Les ouvrages et comptes-rendus doivent être envoyés à:

Dr Bert Peeters

French and Francophone Studies

European Languages and Cultures

Macquarie University

North Ryde, NSW 2 I09

Australia

Email: bert.peeters@mq.edu.au

Les langues du JFLS sont l'anglais et le français. Les auteurs sont invités à soumettre articles et comptes-rendus dans la langue qu'ils maitrisent le mieux.

Aucun article présenté au JFLS n'aura ni été soumis simultanément pour une évaluation à une autre revue scientifique, ni fait l'objet d'une publication préalable ailleurs.

COPYRIGHT

Les auteurs doivent obtenir eux-mêmes les autorisations de citation lorsqu'elles sont soumises à copyright. Il sera demandé aux auteurs dévolution de copyright au profit de Cambridge University Press, sous des conditions à préciser.

PRÉPARATION DES MANUSCRITS

I. Les propositions d'articles doivent être soumises sous forme électronique, logiciel Microsoft Word ou Rich Text Format (.rtf) à jfls@newcastle.ac.uk. (La voie électronique permet une évaluation plus rapide.)

2. Tous les manuscrits soumis à JFLS sont évalués de façon complètement anonyme. Toute référence à l'auteur et tout matériel permettant d'identifier l'auteur doivent donc être éliminés (mais peuvent cependant être inclus dans un document séparé ou email, si besoin est).

3. La longueur des articles sera normalement entre 6000 et 8000 mots. L'auteur indiquera à la fin le nombre de mots. Les propositions de comptes-rendus ne dépasseront pas le nombre de mots agréé au préalable.

4. Établis sur papier $\mathrm{A}_{4}$ (ou de format équivalent), les manuscrits auront double interligne et les marges ne seront pas inférieures à $4 \mathrm{~cm}$ (I.5 pouces). 
5. Les manuscrits d'articles seront précédés d'un résumé d'environ Ioo mots présentant le contenu conceptuel de la contribution. Le résumé en double interligne sera présenté sur page séparée.

6. Pour les articles comme pour les comptes-rendus, tous les paragraphes sauf le premier commenceront par un retrait. Il n'y aura pas d'espace supplémentaire entre les paragraphes. Les paragraphes ne seront pas numérotés.

7. Les citations seront introduites par des guillemets simples, les double guillemets n'étant utilisés que pour les citations à l'intérieur de citations. Les citations de plus de 60 mots environ seront disjointes du texte et décalées de la marge gauche. Elles seront présentées sans guillemet.

8. Les tableaux, figures et graphiques, à l'exclusion des simples règles, exemples et formules, seront présentés chacun sur page séparée. Ils seront numérotés en continu de façon appropriée 'Figure 2', 'Tableau 4'. Dans le texte, on y renverra par ce numéro et jamais par une formule du genre 'voir la figure suivante'.

9. Autant que possible, les transcriptions phonétiques seront conformes à l'Alphabet Phonétique International (API/IPA). Elles n'excéderont pas en étroitesse ni en précision ce qui est absolument nécessaire à l'analyse présentée.

Io. On évitera les allusions sexistes et autrement blessantes.

I I. Lorsqu'un article a été accepté, on demandera à l'auteur de fournir une copie de la version finale sous forme Microsoft Word ou .rtf, en plus de la version finale papier (ou .pdf). L'éditeur se réserve le droit de modifier le manuscrit si la version électronique fournie par l'auteur se révèle inadéquate.

I2. Les manuscrits, tant d'articles que de comptes-rendus, sont définitifs et les épreuves ne doivent pas donner lieu à des révisions d'auteur.

\section{RÉFÉRENCES}

I. On évitera, autant que faire se peut, les notes infrapaginales.

2. Pour les citations et références, on indiquera dans le corps du texte le nom de l'auteur, la date de publication et les numéros de pages entre parenthèses (Dupont, 2002: 56-58). Lorsque cela est nécessaire, on distinguera les publications d'un même auteur et d'une même année par des lettres minuscules $(a, b, c)$ placées après la date. Les références multiples seront ordonnées par date et séparées par des point-virgules. Pour les co-auteurs, on utilisera 'et' et non ' $\&$ '.

3. La liste complète des références citées, présentée en ordre alphabétique de nom d'auteur et en double interligne, sera jointe à la fin de l'article. On indiquera le lieu de publication ainsi que léditeur. Les titres de livres, articles et comptes-rendus seront complets et développés conformément aux exemples ci-dessous:

Adam, J.-M. (1999). Linguistique textuelle: des genres de discours aux textes. Paris: Nathan.

Balibar-Mrabti, A. (dir.) (1997). La Synonymie. = Langue Française I28. Paris: Larousse.

Basset, P., Amelot, A., Vaissière, J. et Roubeau, B. (200I). Nasal airflow in French spontaneous speech. Journal of the International Phonetic Association, 3 I: 87-99.

Bentolila, F. (1988). Autour du verbe. La Linguistique, 24.I: 3-I4I.

Bilger, M. (200I). Retour sur 'le futur' dans les corpus de français parlé. Recherches sur le Français Parlé, I6: I77-I 88 .

Brugmann, K. (I906). Grundriss der vergleichenden Grammatik der indo-germanischen Sprachen, $2^{\text {ième }}$ éd., vol. 2, I ère partie. Leipzig: Trubner.

Johnson, K. (2000). Grammaticalization chains and French complex-inversion. Dans: S. N. Dworkin et D. Wanner (dir.), New Approaches to Old Problems. Amsterdam: Benjamins, pp. I $83-198$.

Kaye, A. S. (2003). Compte-rendu de: I. Fónagy, Languages Within Language. Language, 79: 652. 
Weidenbusch, W. (1993). Funktionen der Präfigierung: präpositionale Elemente in der Wortbildung des Französischen. (Beiheft zur Zeitschrift für Romanische Philologie, 247). Tübingen: Niemeyer.

\section{ÉPREUVES}

Les premières épreuves seront envoyées aux auteurs, ou aux personnes désignées par eux. Les épreuves corrigées seront retournées sous trois jours, par avion si nécessaire, à l'éditeur chargé de la production du numéro. Les auteurs de comptes-rendus ne corrigent pas d'épreuves.

\section{Journal of French Language Studies}

\section{Notes for Contributors}

Contributions and correspondence should be sent to:

Professor Florence Myles

University of Essex

Department of Language and Linguistics

Wivenhoe Park

Colchester $\mathrm{CO}_{4}{ }_{3} \mathrm{SQ}$

UK

E-mail: jfls@newcastle.ac.uk

Material for review and review copy should be sent to:

Dr Bert Peeters

French and Francophone Studies

European Languages and Cultures

Macquarie University

North Ryde, NSW 2109

Australia

Email: bert.peeters@mq.edu.au

The languages of the journal are French and English. Contributors should submit articles and reviews in their first language. Submission of an article is taken to imply that it has not been previously published, and has not been submitted for publication elsewhere.

\section{COPYRIGHT}

Authors are responsible for obtaining necessary permissions to quote copyright material. They will be requested to assign their copyright, on certain conditions, to Cambridge University Press.

\section{PREPARATION OF MANUSCRIPTS}

I. Typescripts of articles should be submitted in electronic format, using Microsoft Word software, together with one print-out identical in all respects to the electronic version. (Electronic submission speeds up the international refereeing process.) Articles should normally be between 6000 and 8000 words. Authors should indicate the approximate number of words at the end of their text. Typescripts of reviews should be submitted in two copies, or in electronic format. Reviews should not exceed the number of words suggested 


\section{Notes for Contributors}

in each case. Typescripts, whether of articles or reviews, should be definitive, and author's revisions should not be made at proof stage.

2. All copy must be double-spaced throughout on $\mathrm{A}_{4}$ paper (or equivalent), with margins of at least $4 \mathrm{~cm}$ (I.5 inches).

3. The typescript of an article should be accompanied by an abstract of about Ioo words summarising its conceptual content. It should be typed (double-spaced) on a separate page.

4. In both articles and reviews, all paragraphs except the first are indented. There is no blank line between paragraphs. Paragraphs are not individually numbered.

5. Quotations should be marked by single inverted commas, with double inverted commas reserved for quotations within quotations. Quotations longer than about 60 words should be set off from the text and indented from the left-hand margin, without inverted commas.

6. Tables, charts and diagrams (though not simple rules, examples or formulae) must each appear on a separate page, and must be labelled 'Figure 2', 'Table 4', as appropriate. Intext references should use the same number, and never an expression like 'see the following diagram'.

7. Boldface, italic type and SMALL CAPITALS may be indicated by using software functions, provided that this is done systematically. Otherwise, italics should be indicated by a single underline, bold by wavy underlining, and small capitals by a double underline. The two systems must not be mixed.

8. Phonetic transcriptions should, wherever possible, make use of the symbols of the International Phonetic Alphabet, and should be no 'narrower' than is absolutely necessary for the purpose.

9. Sexist and other offensive language should be avoided.

Io. When an article has been accepted for publication, authors are asked to send an electronic copy of the final version using Microsoft Word software, together with the hard copy typescript. However, the publisher reserves the right to typeset material by conventional means if an author's electronic version proves unsatisfactory.

\section{CITATIONS}

\section{Footnotes should as far as possible be avoided.}

2. Citations in the body of the text should give author's surname, date of publication and page number in parentheses, as in (Dupont, 2002: 56-58). Where a second or subsequent work by a particular author in the same year is cited, references should be distinguished by letters $(\mathrm{a}, \mathrm{b}, \mathrm{c})$ placed after the date. Multiple references should be ordered chronologically and separated by semicolons. Co-authors should be indicated by 'and' and not by ' $\&$ '.

3. The complete list of references cited, arranged alphabetically by first author's surname should be typed double-spaced at the end of the article. Give place of publication and the publisher. Titles of books, articles and journals should be given in full. References will normally match one of the following patterns:

Adam, J.-M. (1999). Linguistique textuelle: des genres de discours aux textes. Paris: Nathan.

Balibar-Mrabti, A. (ed.) (I997). La Synonymie. = Langue Française I28. Paris: Larousse.

Basset, P., Amelot, A., Vaissière, J. and Roubeau, B. (200I). Nasal airflow in French spontaneous speech. Journal of the International Phonetic Association, 3 I: 87-99.

Bentolila, F. (I988). Autour du verbe. La Linguistique, 24. I: 3-I4I.

Bilger, M. (200I). Retour sur 'le futur' dans les corpus de français parlé. Recherches sur le Français Parlé, I6: I77-I 88.

Brugmann, K. (I906). Grundriss der vergleichenden Grammatik der indo-germanischen Sprachen, $2^{\text {nd }}$ edn, vol. 2, part I. Leipzig: Trubner.

Johnson, K. (2000). Grammaticalization chains and French complex-inversion. In: S. N. Dworkin and D. Wanner (eds), New Approaches to Old Problems. Amsterdam: Benjamins, pp. I83-I98. 
Kaye, A. S. (2003). Review of: I. Fónagy, Languages Within Language. Language, 79: 652.

Weidenbusch, W. (1993). Funktionen der Präfigierung: präpositionale Elemente in der Wortbildung des Französischen. (Beiheft zur Zeitschrift für Romanische Philologie, 247). Tübingen: Niemeyer.

\section{PROOFS}

First proofs only will be sent to authors (or their nominee) who will be expected to correct and return them to the Production Editor, by airmail where appropriate, within three days of receipt. Proofs of reviews are not sent to authors.

\section{OFFPRINTS}

Twenty-five free offprints are supplied to the writers of published articles, these to be shared between joint authors. Further offprints may be purchased if ordered at proof stage. Authors of reviews receive one copy only. 


\section{Bilingualism: Language and Cognition}

\section{Editor}

Jürgen M. Meisel, Hamburg University, Germany David W. Green, University College London, UK

Ping Li, Pennsylvania State University, USA

Carmen Silva-Corvalán, University of Southern California, USA

Bilingualism: Language and Cognition is an international peer-reviewed journal focusing on bilingualism from a cognitive science perspective. The aims of the journal are to promote research on the bilingual person and to encourage debate in the field. The domains covered are the following: bilingual language competence, perception and production, bilingual language acquisition in children and adults, neurolinguistics of bilingualism (in normal and brain-damaged populations), and non-linguistic cognitive processes in bilinguals. Bilingualism carries articles and research notes on all aspects of the bilingual person, and is published three times a year.

\section{Price information}

is available at: http://journals.cambridge.org/bil

\section{Free email alerts}

Keep up-to-date with new material - sign up at

http://journals.cambridge.org/alerts

To subscribe contact Customer Services

\section{in Cambridge:}

Phone +44 (0) 1223326070

Fax $+44(0) 1223325150$

Email journals@cambridge.org

\section{in New York:}

Phone +1 (845) 3537500

Fax $+1(845) 3534141$

Email

subscriptions_newyork@cambridge.org 
Journal of

Linguistics

The Journal of the Linguistics Association of Great Britain

\section{Editors}

Nigel Fabb, University of Strathclyde, UK

Caroline Heycock, University of Edinburgh, UK

Robert D. Borsley, University of Essex, UK

Journal of Linguistics has as its goal to publish articles that make a clear contribution to current debate in all branches of theoretical linguistics. The journal also provides an excellent survey of recent linguistics publications, with around thirty book reviews in each volume and regular review articles on major works marking important theoretical advances.

'The Journal of Linguistics is one of the top journals for theoretical linguistics. It's chock full of new ideas and wonderfully free of theoretical orthodoxy.' Ivan Sag, Stanford University.

\section{Price information}

is available at: http://journals.cambridge.org/lin

\section{Free email alerts}

Keep up-to-date with new material - sign up at http://journals.cambridge.org/alerts

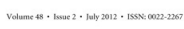

Journal of Linguistics

1

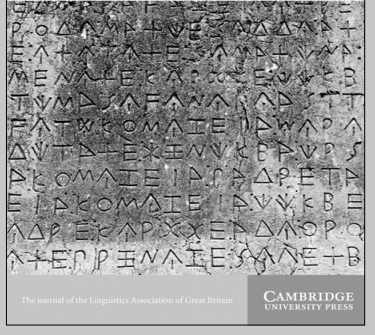

Journal of Linguistics

is available online at:

http://journals.cambridge.org/lin

To subscribe contact Customer Services

in Cambridge:

Phone +44 (0)1223 326070

$\mathrm{Fax}+44(0) 1223325150$

Email journals@cambridge.org

\section{in New York:}

Phone +1 (845) 3537500

Fax +1 (845) 3534141

Email

subscriptions_newyork@cambridge.org 
Information on Journal of French Language Studies and all other Cambridge Journals can be accessed via journals.cambridge.org and in North America via www.cup.org This journal issue has been printed on FSC-certified paper and cover board. FSC is an independent, non-governmental, not-for-profit organization established to promote the responsible management of the world's forests. Please see www.fsc.org for information.

Copying. This journal is registered with the Copyright Clearance Center, 222 Rosewood Drive, Danvers, MA. OI923. Organizations in the USA who are also registered with C.C.C. may therefore copy material (beyond the limits permitted by sections 107 and Io8 of US copyright law) subject to payment to C.C.C. of the per-copy fee of $\$$ I2.00. This consent does not extend to multiple copying for promotional or commercial purposes. Code 0959-2695/2008 \$12.00.

ISI Tear Sheet Service, 350I Market Street, Philadelphia, Pennsylvania 9I904, USA, is authorized to supply single copies of separate articles for private use only.

Organizations authorized by the Copyright Licensing Agency may also copy material subject to the usual conditions.

For all other use, permission should be sought from Cambridge or the American Branch of Cambridge University Press.

Advertising. Enquiries about advertising in this journal should be sent to The Advertising Promoter, Journals Group, Cambridge University Press. 


\section{Journal of French Language Studies}

JULY 2013 VOLUME 23 NUMBER 2

\section{CONTENTS}

\section{ARTICLES}

Allez donc sortir des sentiers battus! La production de l'effet de sens extraordinaive par aller et venive

JACQUES BRES AND EMMANUELLE LABEAU

Le détachement d'objets indirects antéposés dans des énoncés à sujet inversé CATHERINE FUCHS

"Deux-trois mots» sur les déterminants de petite quantité: pluriel contimu et perception sémantique

PHILIPPE GRÉA

Système des démonstratifs médiévanx et exemples de stratégies

communicatives

CÉLINE GUILLOT

La représentation mentale du genve pendant la lecture: état actuel de la recherche francophone en psycholinguistique

PASCAL GYGAX, ORIANE SARRASIN, ARIK LÉVY, SAYAKA SATO AND UTE GABRIEL

The emergence of Noun + Noun constructions with a regressive order in contemporary French?

RUDY LOOCK

Le débit lent des Suisses romands: mythe ou réalité?

SANDRA SCHWAB ET ISABELLE RACINE 